\title{
OVIDUCAL AND UTERINE FLUIDS
}

\author{
H. M. BEIER \\ Anatomisches Institut, Christian-Albrechts-Universität, \\ Olshausenstrasse 40-60, D-2300 Kiel, Germany
}

Our knowledge about the oviducal functions is still incomplete. The Fallopian tube is not merely a conduit for the passage of spermatozoa and ova, but it provides a favourable environment, by virtue of its luminal fluid, for the gametes and for the fertilized and cleaving ovum (Hamner \& Fox, 1968, 1969; Stegner, 1969; Hamner, 1971). Furthermore, the uterine environment doubtless provides shelter and nourishment for the developing and implanting conceptus. During the whole period of gestation the embryo depends upon the milieu provided by the maternal organism, and even during pre-implantation there exists a well documented dependency of the blastocyst upon the maternal substrates, provided by the oviducal and uterine tissues. From the very beginning of development, from the establishment of an individual genome, there exist two closely related systems: the embryonic and the maternal system. But, taking into consideration morphological and biochemical analyses, one must recognize that both these systems comprise several compartments, the structure and significance of which should become clear from what follows. If one investigates the biochemical composition of oviducal and uterine fluids at different times during oestrus and during pre-implantation stages, there will be a spectrum of different time-specific patterns. The analysis of these patterns results in a conclusive assessment of the conditions that the maternal and embryonic systems need for their synchronization in terms of time and substrate sequences.

\section{OVIDUCAL AND UTERINE COMPARTMENTS}

This paper is concerned with the maternal system in general and with two organs in particular. The Fallopian tube and the uterus both have physiological and metabolic functions, which are mediated mainly by the luminal epithelia and their secretions. Within the ampullary oviducal mucosa in the rabbit the lining epithelium consists primarily of columnar cells. Beneath the basement lamina is a layer of connective tissue, containing numerous blood vessels. In the rabbit oviduct, ciliated cells with large apically situated nuclei are interspersed with cells whose apices bulge above the ciliated cells and contain prominent secretory granules (Kühnel \& Beier, 1973) (Pl. 1, Fig. 1). Plate 1, Fig. 2 shows an electron micrograph of the oestrual epithelium of the endometrium in the rabbit. The cells reveal no particular signs of secretory activity. Again, many capillaries are located very close beneath the epithelial cells. If, however, we examine the cavum epithelium during Days 4 to 6 post coitum (p.c.), large apical protrusions of cytoplasm indicate an intensive secretory process (Pl. 1, Fig. 3). 
Oviducal and uterine secretions change continuously in volume and in the viscosity and concentration of their constituents (Lutwak-Mann, 1966; Kulangara, 1972). In the physicochemical and biochemical alterations during preimplantation stages, electrolytes, carbohydrates, amino acids, mucosubstances, proteins, nucleic acids, steroids and proteo-hormones are involved. This is true in all mammalian species, but remarkable species differences have been substantiated (for review, see Blandau, 1971). For manifold reasons we have chosen the rabbit as the object of our studies in reproduction.

Hydrogen ion concentrations in oviducal and uterine fluids reveal significant differences in $\mathrm{pH}$ values for different sites of the genital tract, as demonstrated by Petzoldt (1971). His results show a decrease in $\mathrm{pH}$ values from the oviducal infundibulum to the isthmus. No typical variation in these relationships could be established during pre-implantation (Text-fig. 1). The $\mathrm{pH}$ value of the uterine fluid is significantly higher at the antimesometrial than at the mesometrial site. The values decrease from oestrus to implantation, and from 4 days after mating these uterine values are lower than the values for the site of the cervix (Text-fig. 2). Furthermore, measurements of sodium, potassium, calcium and other ions present evidence of clearly different compartments of serum, oviducal and uterine fluid, and of course blastocyst fluid as well. Earlier results obtained by Lutwak-Mann (1966, 1971) and Kirchner (1969) from analyses of other constituents of small molecular size in the rabbit uterus, e.g. amino acids, bicarbonate, free carbohydrates and metabolites, also supported this conclusion.

\section{EXPLANATION OF PLATES 1 AND 2}

\section{PLATE 1}

FIG. 1. Morphology of the rabbit Fallopian tube epithelia. Semi-thin section of oviducal ampulla of a pseudopregnant animal, 6 days after injection of 50 i.u. HCG. Note abundance of secretory granules within secretory cells and their apical protrusions. Azure-IImethylene-blue staining, $\mathrm{LM} \times 640$.

FIG. 2. Endometrial epithelium of the rabbit at oestrus. Cylindrical epithelial cells without any particular signs of secretory activity, apical cell border with large number of microvilli. $\mathrm{EM} \times \mathbf{4 4 0 0}$.

Fig. 3. Endometrial epithelium of the rabbit uterine cavum at pre-implantation time. Uitrastructural picture from a pseudopregnant animal, 6 days after injection of 50 i.u. HCG. Apical protrusions of the cells contain a large number of mitochondria and granular endoplasmic reticulum. $\mathbf{E M} \times 7000$.

\section{PLATE 2}

FIG. 4. Disc electrophoretic protein patterns of rabbit oviducal fluid at different preimplantation stages of normal pregnancy: (a) 1 day p.c.; (b) 2 days p.c.; (c) 3 days p.c.; (d) 4 days p.c.; (e) 6 days p.c. ALB, albumin; TF, transferrin. From Dies (1972).

FIG. 5. Disc electrophoretic protein patterns of human genital tract fluids. Flushed secretion obtained after hysterectomy. Human blood serum pattern (a), endometrial secretion from the 14th day of the menstrual cycle (b), oviducal fluid from the 15th day of the menstrual cycle (c). Specimens of serum and oviducal fluid had been obtained from the same patient. PR, Pre-albumin; ALB, albumin; TR, transferrin; POT, post-transferrin band. Modified from Beier et al. (1970).

FIG. 6. Disc electrophoretic analysis of leucine aminopeptidase in rabbit uterine secretion. LAP-specific staining (a) after Nachlas, Crawford \& Seligman (1957), LAP, red staining band in post-transferrin position; Amido black staining (b), modified from Beier, Kühnel \& Petry (1972). 


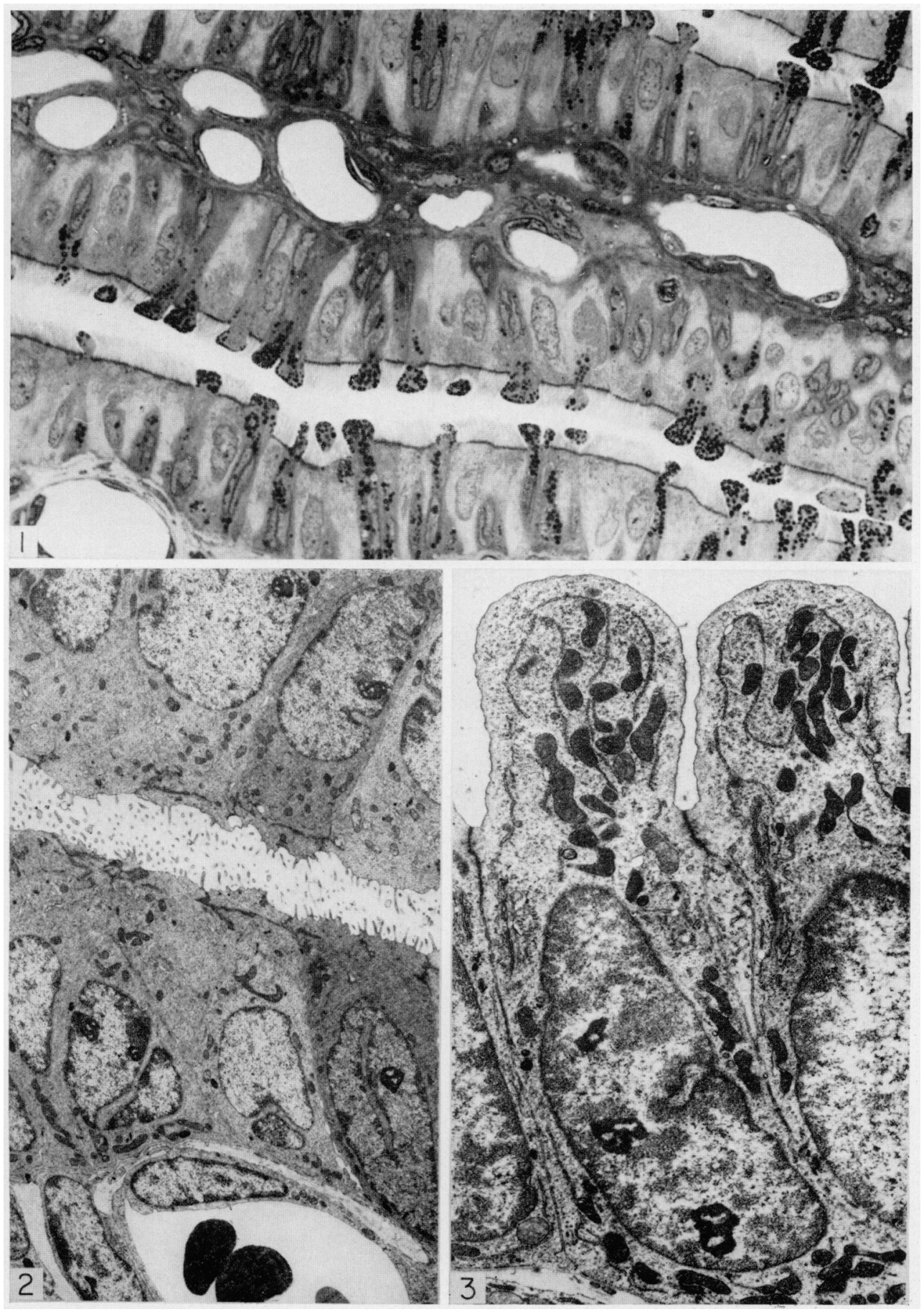

(Facing p. 222) 


\section{PLATE 2}

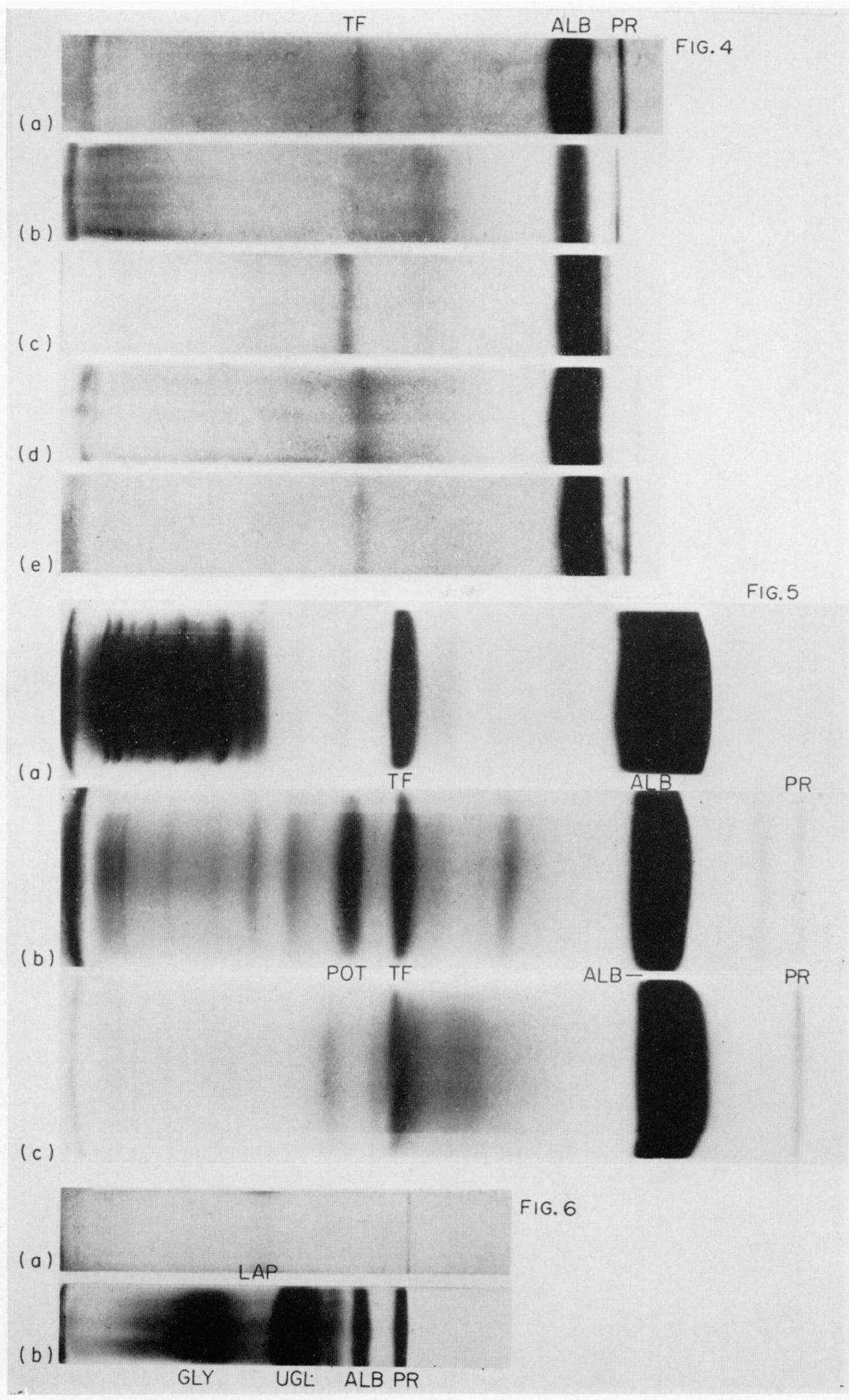


PLATE 3

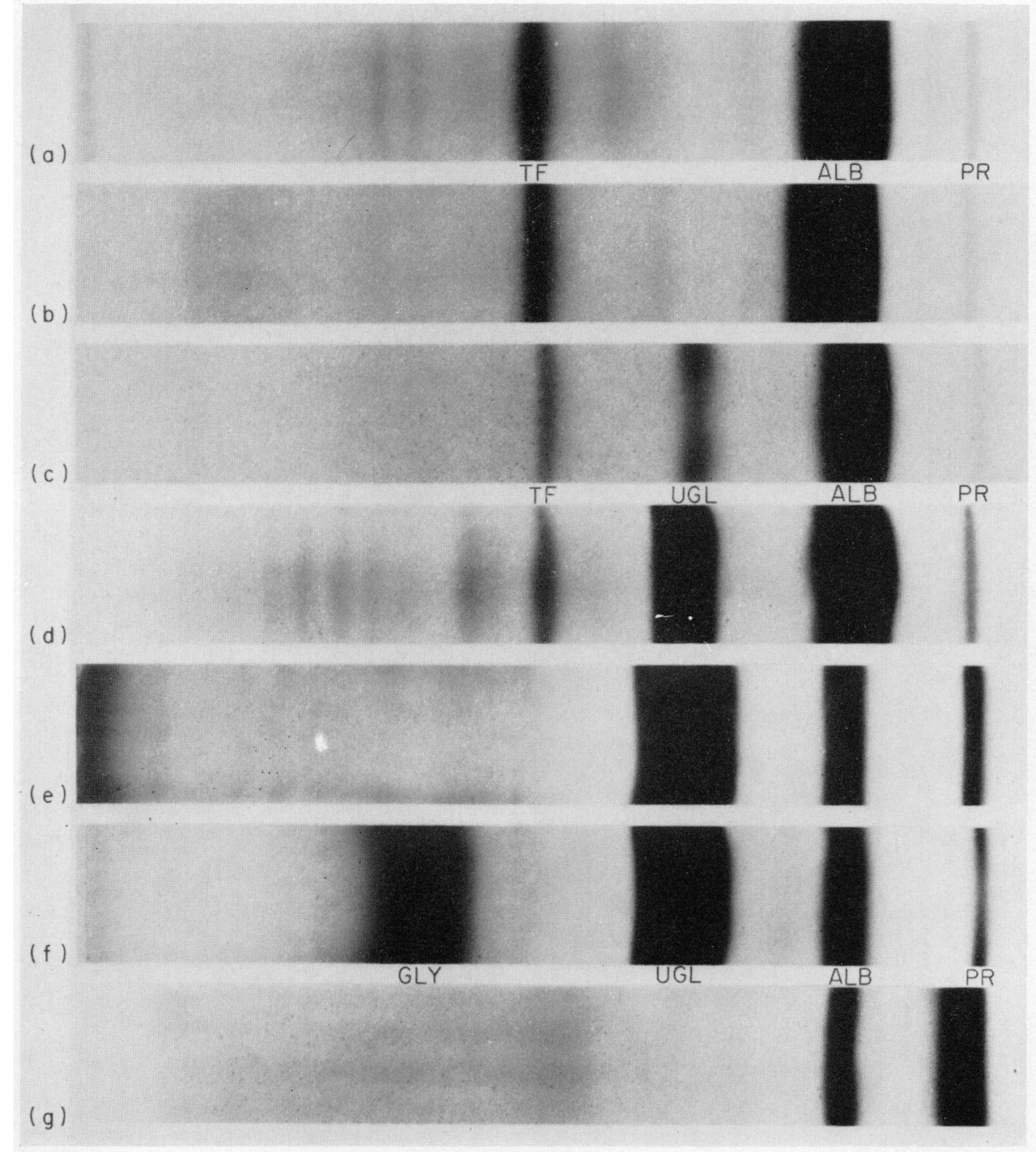

FIg. 7. Disc electrophoretic protein patterns of rabbit uterine secretion from experimental delayed secretion. Oestrous pattern (a), oestrous pattern after two injections of 100 and $150 \mu \mathrm{g}$, respectively, oestradiol-17 $\beta$ (b), delayed secretion from Day 4 p.c. (c), Day 6 p.c. (d), Day 8 p.c. (e), Day 12 p.c. (f) and Day 16 p.c. (g). PR, pre-albumin; ALB, albumin; UGL, uteroglobin; TF, transferrin; GLY, $\beta$-glycoprotein. Acrylamide gel electrophoresis performed at $\mathrm{pH} 9 \cdot 0$, tris-glycine-buffer. 


\section{PLATE 4}
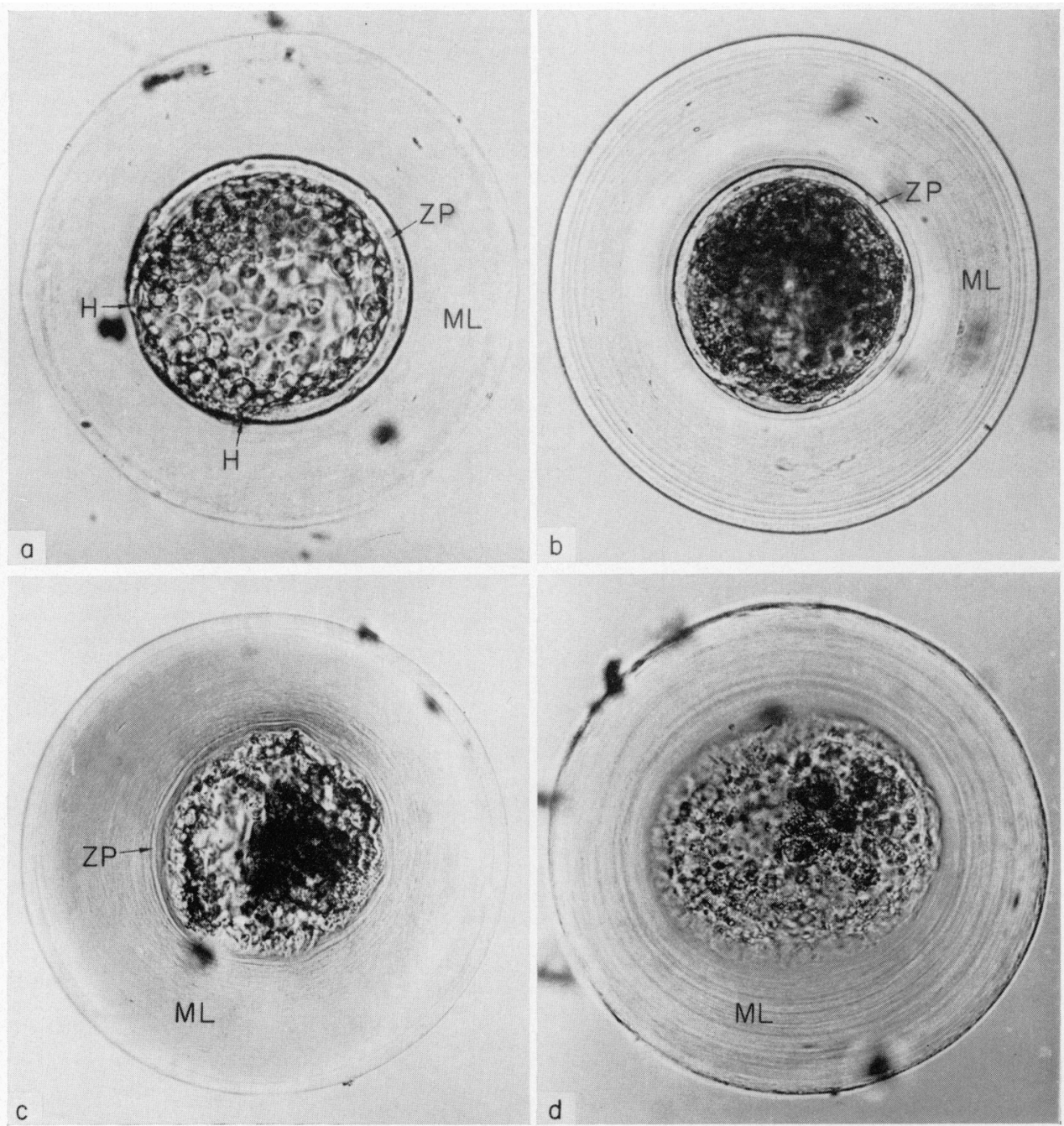

FIG. 8. Blastocysts recovered from delayed secretion uteri of normally mated and oestradiol$17 \beta$-treated animals. All blastocysts were obtained after flushing the uterine cornua at 4 days p.c. (a); 6 days p.c. (b); 8 days p.c. (c) and 18 days p.c. (d). ML, mucoproteid layer; $\mathrm{ZP}$, zona pellucida; $\mathrm{H}$, hernia of blastocyst after rupture of zona pellucida. $L M \times 140$. 


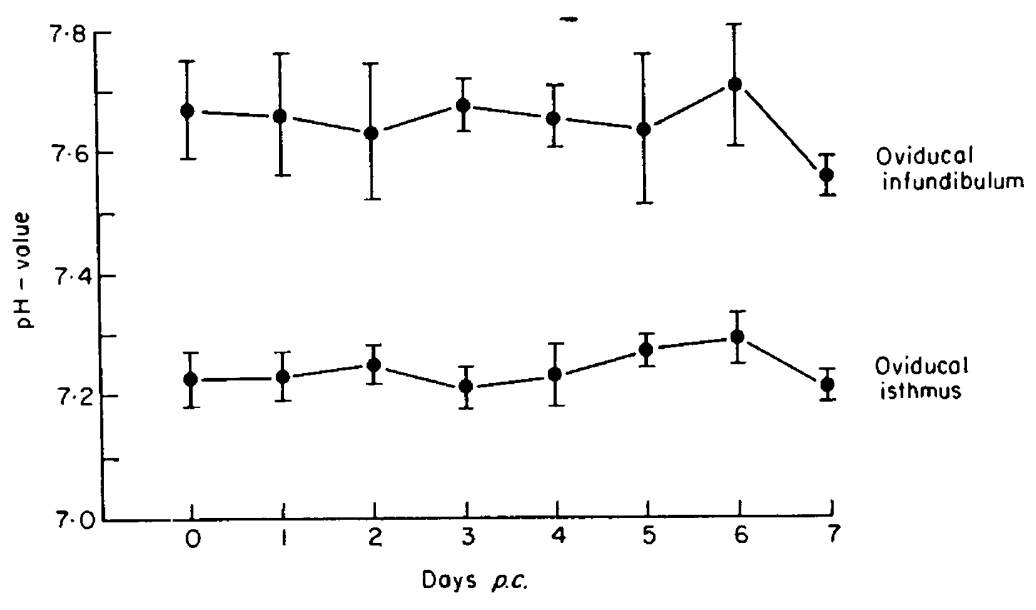

TExT-Fig. 1. The pH-values of oviducal fluid, obtained from the infundibular and isthmic lumen, using glass electrodes in living laparotomized rabbits. Mean values calculated from five measurements, standard errors are indicated. Adapted and modified from Petzoldt (1971).

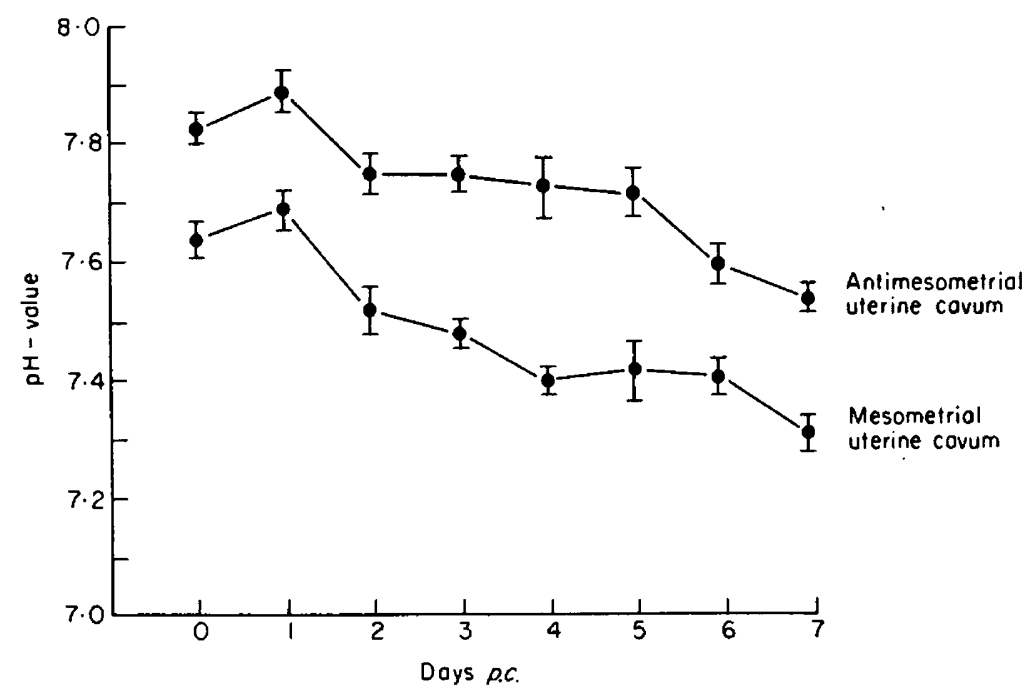

Text-Fig. 2. The pH-values of uterine fluid, obtained from the mesometrial and the antimesometrial site of the cavum, using glass electrodes in living laparotomized rabbits. Mean values calculated from five measurements, standard errors are indicated. Adapted and modified from Petzoldt (1971).

\section{PROTEIN PATTERNS IN OVIDUCAL AND UTERINE FLUIDS}

Compartmentation in the oviduct and uterus has been demonstrated more conclusively from investigations of high molecular size substances, particularly proteins. In recent times, the oviducal and uterine protein secretion has been subjected to analytical polyacrylamide electrophoresis by many investigators and has been compared with several body fluid protein patterns, especially blood 
serum (Schwick, 1965; Kunitake, Nakamura, Wells \& Moyer, 1965; Beier, 1967, 1968a, b, 1972; Kirchner, 1969; Krishnan \& Daniel, 1968; Urzua, Stambaugh, Flickinger \& Mastroianni, 1970; Shapiro, Jentsch \& Yard, 1971; Feigelson \& Kay, 1972). Disc-electrophoretic patterns of rabbit oviducal fluids are shown in Pl. 2, Fig. 4. Dies (1972) found electrophoretical pictures from washed oviducal fluid significantly different from serum protein patterns, but from oestrus until the 6 th day after mating no remarkable changes occurred. Albumin and transferrin appear in proportions comparable with those in serum, but oviducal fluid lacks macroglobulins and some prominent fractions in the post-transferrin and immunoglobulin region. Genital tract specific proteins, such as pre-albumin and uteroglobin, are present in small amounts.

The protein pattern of uterine secretion, obtained by flushing uterine cornua with physiological saline, is not very different from that of oviducal fluid or serum during oestrus; albumin and transferrin appear as the strongest fractions. The prominent bands of serum macroglobulins and lipoproteins are not present in endometrial secretion at oestrus. In pregnancy and in pseudopregnancy, specific protein patterns form. Uterine secretion patterns from Days 4 to 7 p.c. show considerable changes compared to oestrus: a high pre-albumin peak, comparatively little albumin, a pregnancy-specific post-albumin, the predominant uteroglobin-fraction, a broad range of $\beta$-glycoproteins, which shows a considerable change to a prominent peak 7 days p.c. (Text-fig. 3). In pseudopregnant uteri of rabbits a comparable protein pattern develops, and quantitative and chronological differences have been analysed (Beier, 1971; Kühnel, Beier \& Petry, 1971; Beier \& Kühnel, 1973a).

Analytical evidence has recently been accumulated from qualitative and quantitative investigations of oviducal and uterine fluids and blood serum from several laboratory animals, employing acrylamide gel electrophoresis, Ouchterlony double immuno-diffusion and other immuno-electrophoretic techniques. The evidence suggests that, whereas many genital tract fluid proteins are identical to those of serum, several are specific to oviducal or uterine secretion. These observations contribute to the understanding of the genesis of oviducal and uterine fluids. There is a selective transport of serum proteins into the genital tract lumen. The partial disparity in the relative amounts of these few serum protein components in tubal and uterine secretion further emphasizes the selectivity of the transudation process. The presence of unique proteins in oviducal and uterine fluids would seem to reflect the secretory activity of oviducal and endometrial tissues. Chronologically changing patterns reveal the production of secretion which is adapted and co-ordinated in time to early pregnancy and early embryonic development.

Biochemical investigations have identified nine different proteins in the endometrial secretion. Of these, seven have the characteristics of glycoproteins. There is a high content of $\mathrm{N}$-acetyl-neuraminic acid in pre-albumin, glucose in post-albumin and a large quantity of galactose in $\beta$-glycoprotein. Most uterine fluid proteins $(55$ to $60 \%$ ) are relatively small molecules (15 to 70,000$)$. Only a very small percentage may definitely be classified as large proteins (e.g. $\alpha-$ macroglobulin, $\beta$-M-macroglobulin) with a molecular weight between $10^{5}$ and $10^{6}$. 

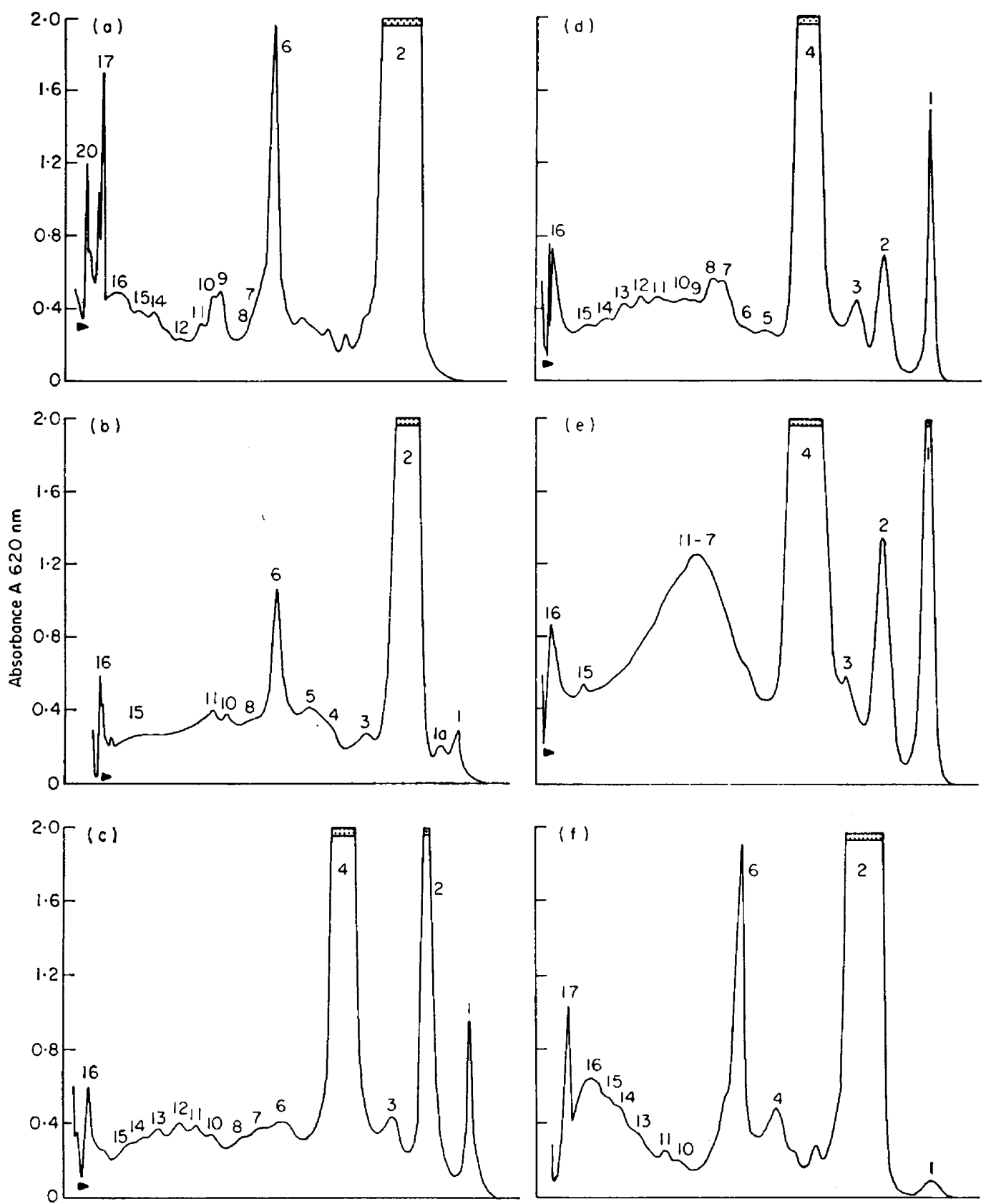

TEXT-FIG. 3. Protein patterns of rabbit blood serum (a), oestrous uterine fluid (b), uterine secretion at normal pregnancy from 4 days p.c. (c), 6 days p.c. (d), 7 days p.c. (e) and 9 days p.c. (f). Protein peaks: 1, pre-albumin; 2, albumin; 3, post-albumin; 4, uteroglobin; 6 , transferrin; 7 to $11, \beta$-glycoproteins, $17 \alpha$-macroglobulin. Disc-electrophoresis, trisglycine-buffer $\mathrm{pH}$ 9.0; Densitometric tracing Zeiss PMQ II. 


\section{STUDIES ON UTEROGLOBIN}

The predominant fraction in the post-albumin region is the pregnancy-specific rabbit uterine protein which has been called uteroglobin (Beier, 1966, 1967). This protein is a small globular macromolecule. Text-figure 4 shows patterns obtained by micro-disc-electrophoresis using $20 \%$ acrylamide and less than 50 $\mu \mathrm{g}$ protein. Uteroglobin moves in front of albumin, when added to serum. It is absent from follicular fluid, but present in oviducal fluid. Immunoelectrophoresis with a specific antiserum revealed the presence of this protein in

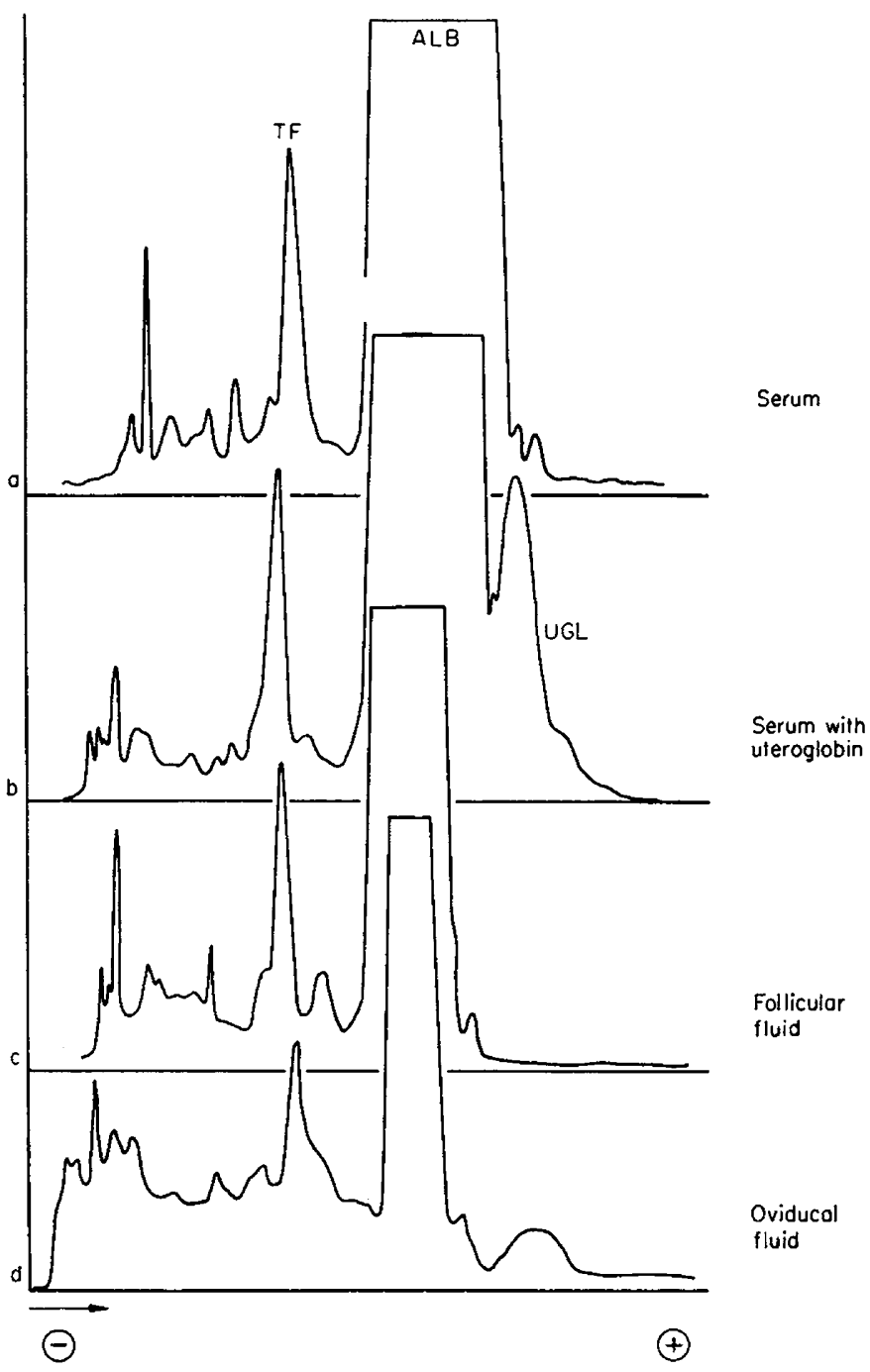

TExT-FIG. 4. Protein patterns of rabbit blood serum (a), blood serum with added uteroglobin (b), follicular fluid (c) and oviducal fluid (d). ALB, albumin; TF, transferrin; UGL, uteroglobin. Micro-disc-electrophoresis, pH 8.8; Densitometric tracing Joyce-Loebl-Doublebeam microdensitometer. Diagram modified from Petzoldt, Dames, Gottschewski \& Neuhoff (1972). 
oviducal and uterine fluid (Dies, 1972). The molecular weight of uteroglobin originally calculated to be 30,000 (apparently identical to the blastokinin fraction, described independently by Krishnan \& Daniel (1967) after uteroglobin had been detected) must be considered somewhat uncertain, since Murray, McGaughey \& Yarus (1972) recently proposed a molecular weight of 15,000 . The previously observed $S_{c}$ of 1.38 Svedberg units of uteroglobin (Beier, $1968 \mathrm{a}, \mathrm{b})$ could be consistent with the small size now reported for this globular protein.

The question of the site of biosynthesis of uteroglobin has been answered by means of a double-antibody immunofluorescence technique, which, by a twofold antigen-antibody reaction, leads to a very sensitive labelling of the protein molecules under investigation (Kirchner, 1972). Uteroglobin is found in the endometrial epithelium even on the day of coitus and reaches a maximum on Days 3 to 4 p.c., that is, 1 day before the maximal concentration of this protein in uterine secretion.

The studies on rabbit uteroglobin raise the question of conditions in other animal species and in the human uterus. As Pl. 2, Fig. 5 demonstrates, protein patterns of human blood serum, endometrial secretion and oviducal fluid do not contain any comparable predominant fraction in the post-albumin region. Specific oviducal and uterine proteins probably exist in the human genital tract, but we have not yet been able to demonstrate these immunologically as was the case with the serum-identical proteins pre-albumin, albumin, orosomucoid, $\alpha_{1}$-antitrypsin, transferrin and the immunoglobulins $\operatorname{IgA}, \operatorname{IgG}, \operatorname{IgM}$. The intra-tubal and intrauterine protein pattern apparently develops not only in the rabbit but in the human being through selection of individual plasma proteins on the one hand and biosynthesis of uterus-specific proteins on the other. Specific protein fractions in the oviducal post-transferrin region have been demonstrated in the monkey by Mastroianni, Urzua, Avalos \& Stambaugh (1969), Mastroianni, Urzua \& Stambaugh $(1970,1972)$ and in the human by Moghissi (1970). The latter was probably identical with the same fraction in our specimen, shown in Pl. 2, Fig. 5.

Biochemical analysis of the uteroglobin fraction is in progress in several laboratories (Beier, 1972; Daniel, 1972; Feigelson \& Kay, 1972; Kirchner, 1972; Petzoldt, Dames, Gottschewski \& Neuhoff, 1972). This protein is probably a glycoprotein with a $5.7 \%$ carbohydrate component, but without sialic acid. Uteroglobin is likely to be a steroid carrier, as work from Daniel and Mastroianni's group suggests (Urzua et al., 1970; Daniel, 1971; Arthur, Cowan \& Daniel, 1972). Binding of progesterone is reported to be significantly higher than that of oestradiol, but some other steroids, such as testosterone, are not bound at all (Arthur et al., 1972).

In this context it may be important to draw attention to the recent findings of Seamark \& Lutwak-Mann (1972) who demonstrated the three progestins, progesterone, $17 \alpha$-hydroxyprogesterone and $20-\alpha-\mathrm{HP}$, in blastocyst fluid of the rabbit.

Always, when I have been discussing uteroglobin and the other pregnancyspecific proteins, the question has been asked, whether these molecules are in any way involved in embryonic development. Once, a critical voice was raised 
about a 'christening fervour' because of the different names for the uteroglobin fraction. In my opinion, it is quite vital to have a working hypothesis about the involvement of oviducal or uterine proteins in embryonic growth, development or implantation. Nevertheless I agree with some research workers who are not fond of protein names which are coined for uncertain embryotrophic and blastocyst-kinetic properties. Our knowledge concerning the biological activity of this protein fraction is still very incomplete and the effects and actions at the molecular site are obscure.

\section{ENZYME ACTIVITIES OF UTERINE FLUID PROTEINS}

Recently we have gained some data on the biological activities of specific uterine proteins, but we must emphasize the preliminary status of our knowledge concerning the complete understanding of the relationship between uterine proteins and embryonic development. Kirchner, Hirschhäuser \& Kionke (1971) showed that $\beta$-glycoprotein is a uterine protease with maximum activity at Day 7 p.c. in the rabbit. Denker (1972) has demonstrated proteolytic activity in the rabbit trophoblast by a substrate film technique. Both proteases develop peak activity during attachment and invasion of the trophoblast, and they seem to be involved in this process. Regulation of protease activity within the rabbit uterus is controlled by uterine protease inhibitors, the activity of which is clearly stimulated by ovarian hormones (Beier, 1970b; Denker, 1972).

Lutwak-Mann (1955) was the first to contribute to our knowledge of endometrial enzymes and their hormonal dependence. She investigated the occurrence and distribution of carbonic anhydrase in the rabbit genital tract and the blastocyst. More recent data substantiate her conclusion that ovarian steroids regulate oviducal and uterine enzymes. Leucine aminopeptidase has been demonstrated to be largely controlled by progesterone. Histochemical analysis shows maximum activity in the cavum epithelium at Days 4 and 5 p.c. in the rabbit uterus (Beier, Petry \& Kühnel, 1970; Denker, 1971). This membranebound enzyme is secreted by detachment of the apical protrusions, described above, into the luminal fluid. Plate 2, Fig. 6 demonstrates this protein to be a specifically staining band in the transferrin region (Beier, Kühnel \& Petry, 1972).

\section{THE GONTROL OF THE PATTERNS OF OVIDUCAL AND UTERINE PROTEIN BY OVARIAN HORMONES}

At this point we should focus our attention on the well-known evidence that ovarian hormones regulate the steady state of oviducal and uterine proteins, their metabolism and finally their involvement in reproductive processes, e.g. capacitation, fertilization, cleavage, blastocyst development and implantation. This is fundamental endocrinology of reproduction since we have learned to influence early pregnancy by ovariectomy and replacement of ovarian hormones. Text-figure 5 outlines an experimental schedule by which, in our laboratory, different exogenously stimulated hormonal imbalances revealed variations in the intrauterine protein fractions, and caused failure of the maternal organism to produce these proteins at the appropriate time. Hormonal treatment without 


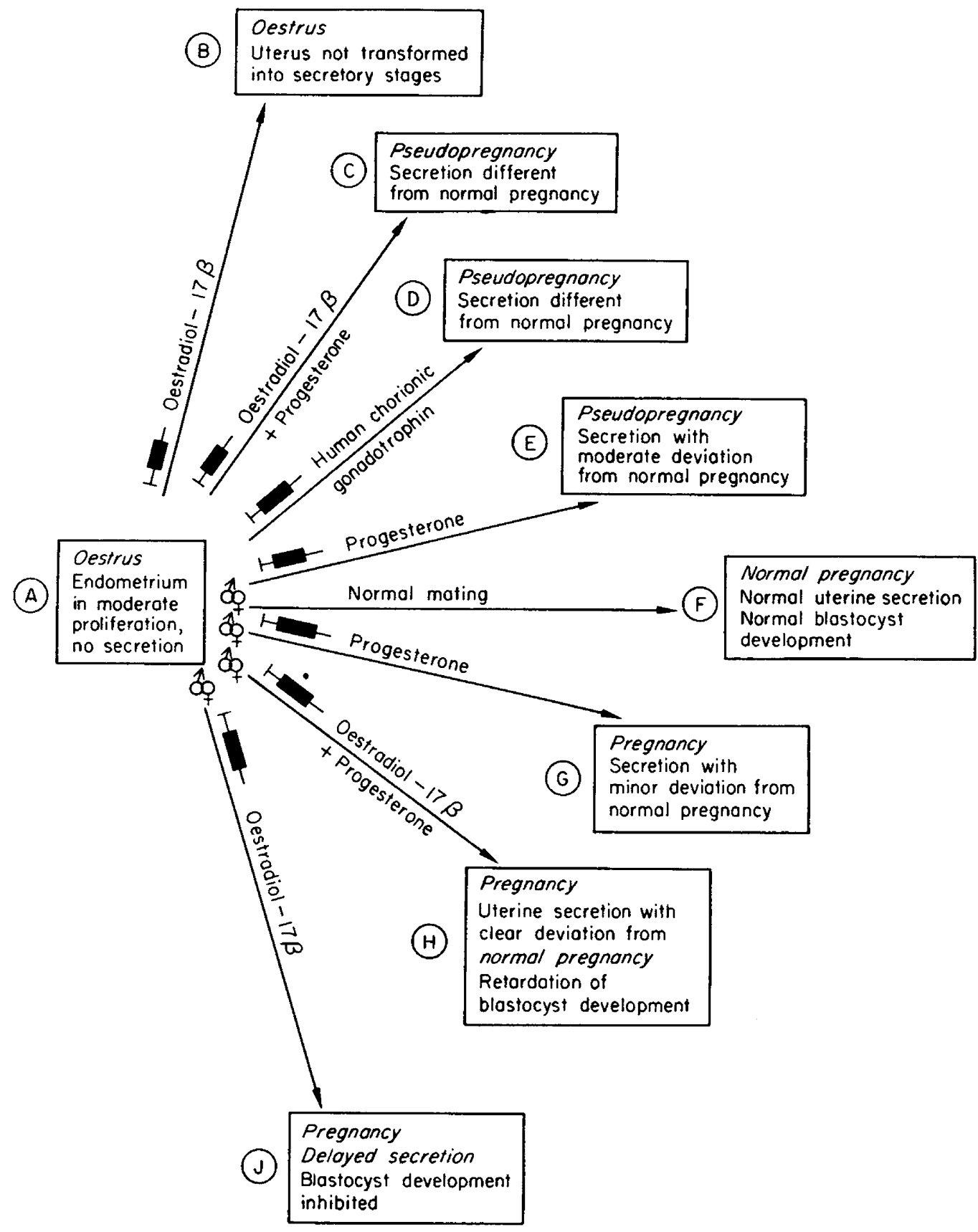

TEXT-FIG. 5. Design of experiments with hormonal imbalances, induced in pseudopregnant and pregnant rabbits. Treatment of normal oestrous animals, analyses each performed on Day 6 p.c. The groups B, C, D, E only received hormone injections without preceding copulation, thus leading to different pseudopregnancies. Dosage of exogenous hormones: HCG, one injection of 20 i.u. i.v.; oestradiol-17 $\beta$, intramuscularly (i.m.) injections of $0.1 \mathrm{mg} 6 \mathrm{hr}$ p.c., and $0.15 \mathrm{mg} 30 \mathrm{hr}$ p.c.; progesterone, i.m. injections of $5.0 \mathrm{mg}$ at Days 1 to 5 p.c. each. 
mating yields abnormal pseudopregnancies. In the course of Exps $\mathbf{H}$ and I embryonic growth had been retarded or even stopped, and no implantation could occur.

Protein patterns of the disturbed pregnancies show considerable variations from the normal pattern by the 6th day p.c., and oestrogen has a most remarkable effect on the development of the protein pattern dynamics in uterine fluid (Beier, 1970a; Beier et al., 1970). Oestradiol, given between the day of mating and Day 3 p.c. in a single injection of 50 to $250 \mu \mathrm{g}$, gives rise to high concentrations of serum-identical proteins, and suppression of uterine-specific proteins (Beier et al., 1970; Beier, Kühnel \& Petry, 1971; Dies, 1972). As Text-fig. 6

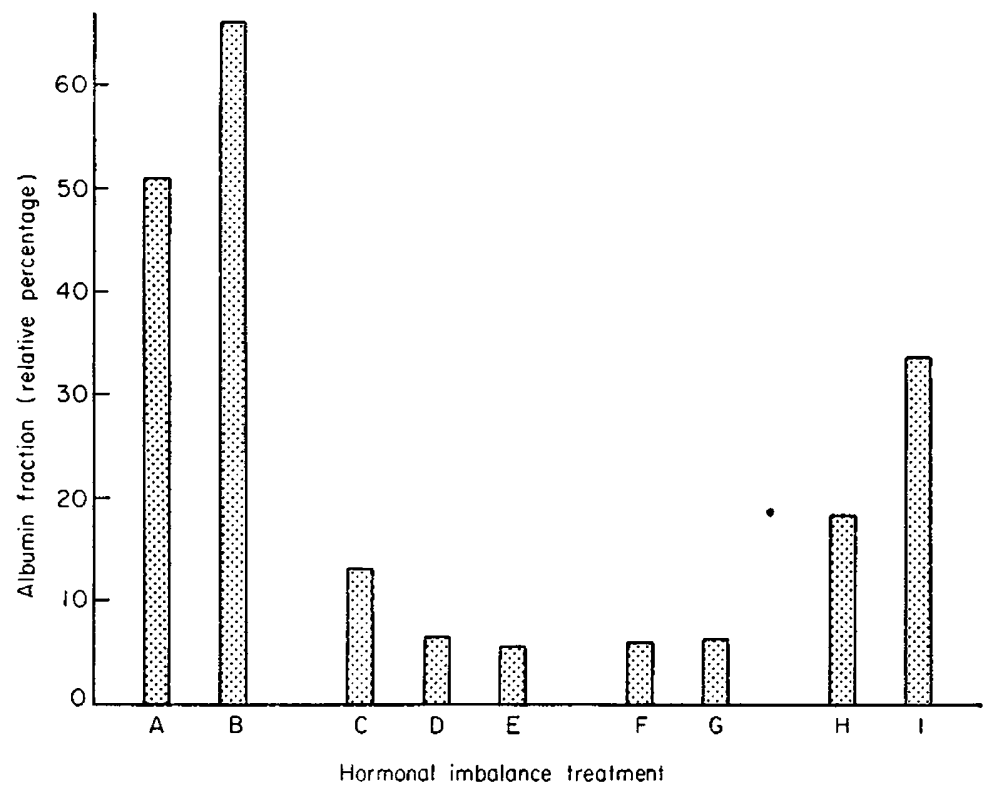

TEXT-FIG. 6. Relative percentage of albumin in rabbit uterine secretion of hormonetreated animals from Exps A to I, outlined in Text-fig. 5 .

shows, all oestrogen-dominated situations reveal high proportions of albumin (Exps A, B and I), but there are low concentrations when uterine protein secretion is under the control of progesterone (Exps G, D, E and F, G, H). The reverse situation with uteroglobin concentrations in uterine secretion may become evident from Text-fig. 7. Uterine pre-albumin, post-albumin and uteroglobin are strictly controlled by progesterone. These results of our early experiments with ovariectomized rabbits have been confirmed by several research groups (Beier et al., 1970, 1971; Urzua et al., 1970; Arthur et al., 1972). One can find uteroglobin and other pregnancy-specific proteins in considerable amounts in the uterine secretion of ovariectomized rabbits evoked simply by progesterone or some synthetic progestins. It would even appear that oestrogen priming is not necessary for the onset of secretion of these proteins (Text-fig. 8). We should draw attention to the fact that these hormone effects could be demonstrated clearly in the uterus, but not in the oviduct. This seems to be a remarkable 


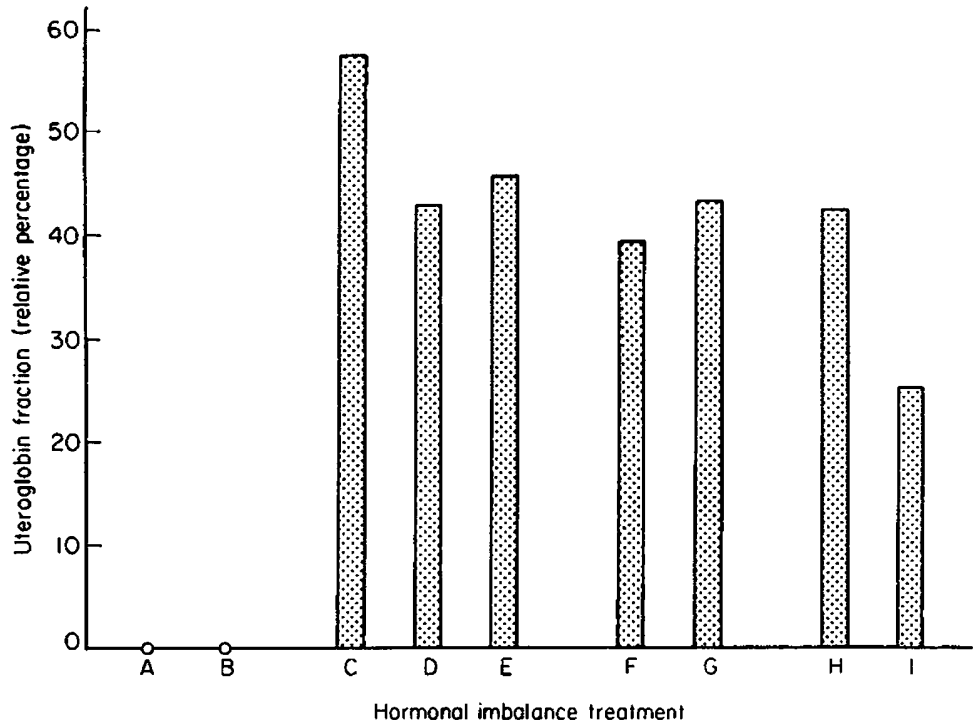

TEXT-Fic. 7. Relative percentage of uteroglobin in rabbit uterine secretion of hormonetreated animals from Exps A to I, outlined in Text-fig. 5.

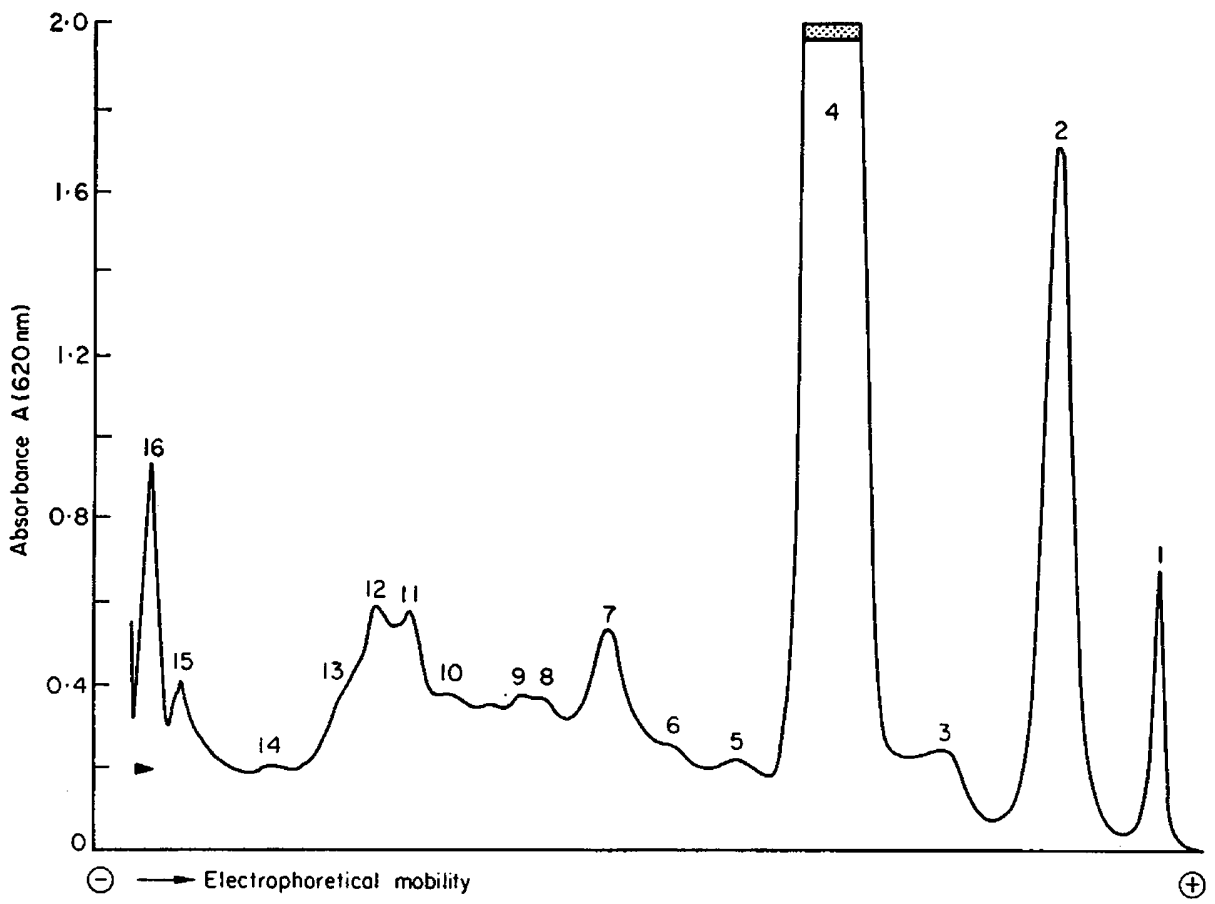

Text-FIG. 8. Protein pattern of rabbit uterine secretion, obtained from ovariectomized animals after 5 days of progesterone treatment $(5 \mathrm{mg}$ progesterone daily). Pregnancy specific proteins occur without oestrogen-priming treatment. Protein peaks: 1 , prealbumin; 2 , albumin; 3 , post-albumin; 4 , uteroglobin; 6 , transferrin; $7, \beta$-glycoprotein. 


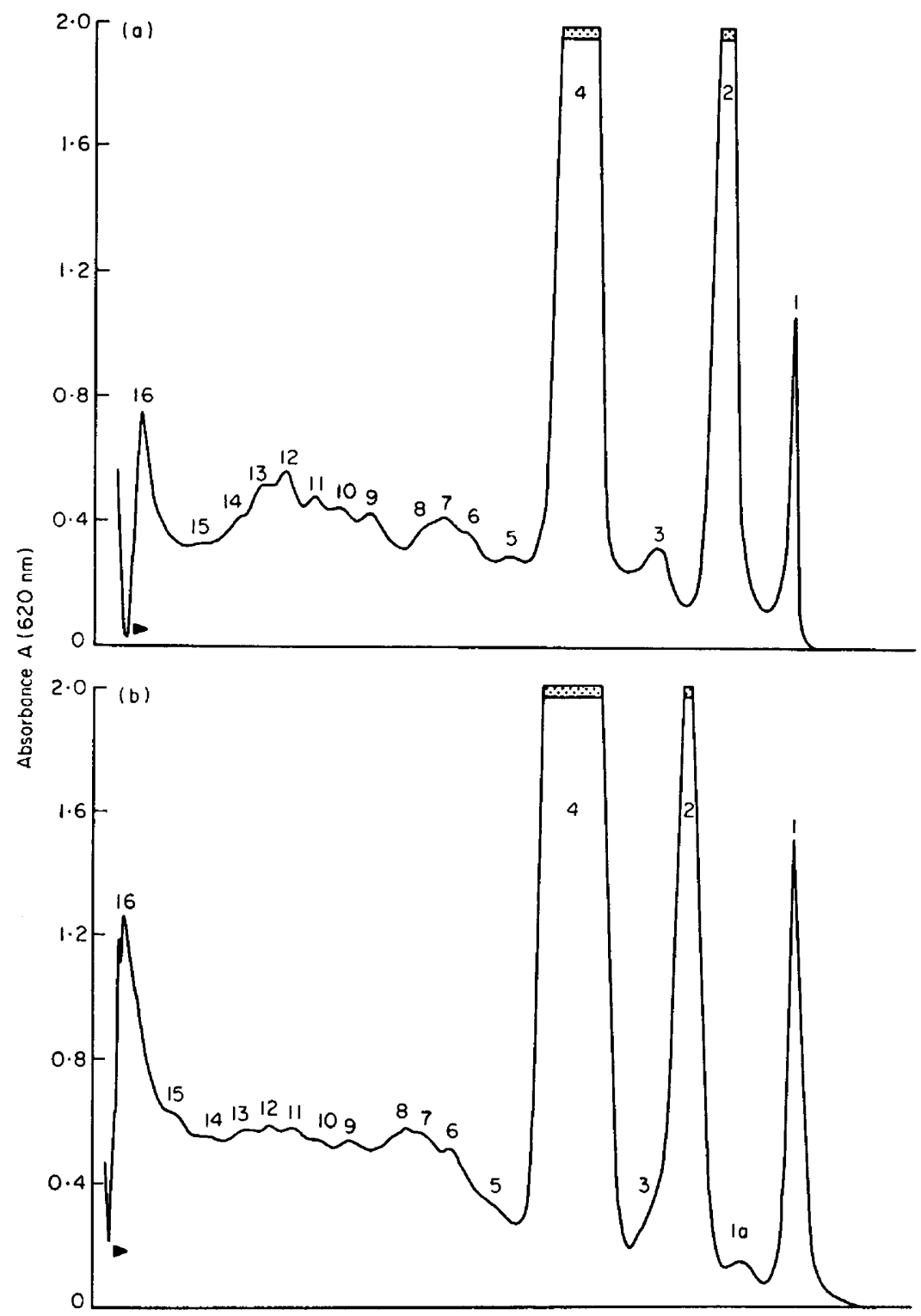

TExT-FIG. 9. Comparison of protein patterns from rabbit uterine secretions at 4 days p.c. pseudopregnancy (a), and 8 days p.c. delayed secretion pregnancy (b). Protein peaks, see Text-figs 3 and 8.

difference between target tissues. We never saw such dramatic changes in oviduct fluid components as happened in the uterine secretion.

\section{DELAYED SEGRETION AS AN EXPERIMENTAL MODEL FOR STUDIES ON BLASTOCYST-UTERINE RELATIONSHIPS}

At a certain stage in biochemical and endocrinological research it is advisable to ask about the biological relevance of the experiments and their results. Recently, 


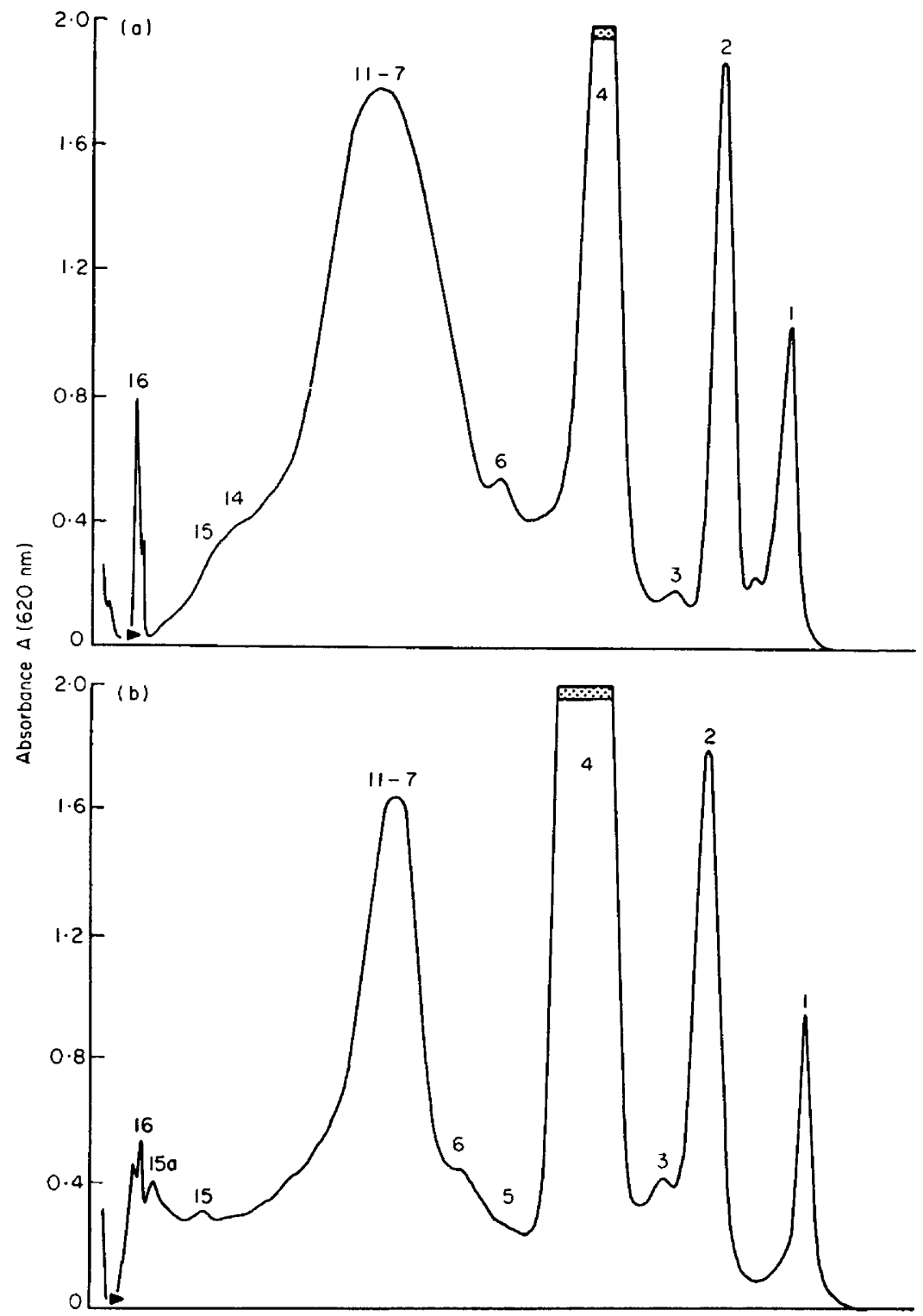

TEXT-FIG. 10. Comparison of protein patterns from rabbit uterine secretions at 7 days p.c. pseudopregnancy (a), and 12 days p.c. delayed secretion pregnancy (b). Protein peaks, see Text-figs 3 and 8.

in our laboratory, a biochemically analysed phenomenon of rabbit reproductive physiology has been the background for a biological experiment. As shown previously (Beier et al., 1971 ; Beier \& Kühnel, 1973b), two injections of oestradiol$17 \beta$ (100 and $150 \mu \mathrm{g}$, respectively) at $6 \mathrm{hr}$ and $30 \mathrm{hr}$ p.c. reveal a delay in the dynamics of uterine protein patterns. The blastocysts of the treated mother undergo retardation. These blastocysts do not implant, as may be demonstrated in Pl. 4, Fig. 8. The secreted protein patterns develop 2 to 5 days later (Pl. 3, 
Table 1. Results of transfer experiments with normal 4-day-old blastocysts, transferred into uteri at different stages during delayed secretion in the rabbit

\begin{tabular}{c|c|c|c|c}
\hline $\begin{array}{c}\text { Reproductive } \\
\text { stage of foster } \\
\text { mother (days p.c.) }\end{array}$ & $\begin{array}{c}\text { Transferred } \\
4-\text { day } \\
\text { blastocysts }\end{array}$ & $\begin{array}{c}\text { Implantations } \\
\text { and uterine } \\
\text { swellings }\end{array}$ & $\begin{array}{c}\text { Embryos } \\
\text { and } \\
\text { young }\end{array}$ & $\begin{array}{c}\text { Time of } \\
\text { laparotomy: p.c. } \\
\text { (days) }\end{array}$ \\
\hline 4 & 11 & 0 & 0 & 10 \\
4 & 6 & 0 & 0 & 10 \\
6 & 11 & 0 & 0 & 12 \\
6 & 6 & 0 & 0 & 12 \\
8 & 9 & 7 & 5 & 14 \\
8 & 10 & 5 & $(5)$ & 38 \\
8 & 7 & 7 & 0 & 14 \\
8 & 7 & 6 & 3 & 39 \\
8 & 6 & 4 & 0 & 16 \\
10 & 4 & 4 & 0 & 16 \\
10 & 5 & 5 & & \\
\hline
\end{tabular}

Table 2. Comparison of transfer success of normal 4-day-old blastocysts, transferred into uteri at different stages during normal pseudopregnancy and 8-day delayed secretion in the rabbit

\begin{tabular}{l|c|c|c|l}
\hline $\begin{array}{c}\text { Reproductive } \\
\text { stage of foster } \\
\text { mother (days p.c.) }\end{array}$ & $\begin{array}{c}\text { Transferred } \\
4-\text { day } \\
\text { blastocysts }\end{array}$ & $\begin{array}{c}\text { No. of } \\
\text { young }\end{array}$ & $\begin{array}{c}\text { \% of } \\
\text { successful } \\
\text { transfer }\end{array}$ & References \\
\hline 0 & 66 & 0 & 0 & Chang (1950) \\
1 & 74 & 0 & 0 & Chang (1950) \\
2 & 36 & 9 & $25 \cdot 0$ & Chang (1950) \\
3 & 54 & 31 & 57.5 & Chang (1950) \\
4 & 121 & 71 & $58 \cdot 7$ & Chang (1950) \\
4 & 38 & 22 & $57 \cdot 9$ & Mootz (1971) \\
5 & 62 & 17 & $36 \cdot 4$ & Chang (1950) \\
6 & 81 & 0 & 0 & Chang (1950) \\
7 to 10 & 109 & 0 & 0 & Chang (1950) \\
8 (delayed & 39 & 15 & $38 \cdot 5$ & Beier, Mootz \& Kühnel (1972) \\
$\quad$ secretion) & 39 &
\end{tabular}

Fig. 7), compared with the normal patterns. These delayed secretion patterns correspond most nearly to the uterine secretion patterns during HCG-stimulated pseudopregnancy, the similarities to which are both quantitative and qualitative (Text-figs 9 and 10).

The question then arises whether such biochemically defined, delayed secretion conditions could support normal egg development and implantation. Therefore, we transferred 4-days-p.c. normal rabbit blastocysts to 8-days-p.c. oestrogen-treated rabbits, with uteri showing delayed secretion. This transfer revealed normal implantations at Days 11 to 12 , which are quite unusual in the rabbit, and the embryos were well developed at Day 14 of the foster mother's reproductive stage (Beier, Mootz \& Kühnel, 1972; Beier, 1973). Summarizing the data of our transfer experiments, as compiled in Table 1, we must emphasize 
that these extensions of transfer asynchrony at 4 days are remarkable, because of the much shorter maximal asynchronous interval of $48 \mathrm{hr}$ reported earlier (Chang, 1950; Adams, 1967, 1970). There exists a quite surprising similarity in transfer success, when comparing our experimental schedule with the reported data in the literature (Table 2). This phenomenon of delayed secretion patterns may be explained by the luteotrophic rôle of oestrogens in the rabbit. Oestrogen, shortly after ovulation, interferes with the onset of progestin-release. In consequence of this disturbed onset of hormonal balance, the whole concert of preimplantation events, thereafter, seems to be delayed. Consequently, this delayed secretion, which has been detected biochemically, provides biological evidence of the need for a proper uterine milieu, and more likely the appropriate proportions of several proteins rather than the presence of only one, to support development of the pre-implantation embryo. Finally, these results indicate the involvement of hormonally controlled secretion of proteins by the uterus in the demands for synchronization of the maternal and embryonic systems, to enable the latter to realize its developmental potential.

\section{ACKNOWLEDGMENT}

The preparation of this paper has been made possible by Grant Be 524/2 from the Deutsche Forschungsgemeinschaft, Bonn-Bad Godesberg, Germany.

\section{REFERENGES}

ADAMs, C. E. (1967) Ovarian control of early embryonic development within the uterus. In: Reproduction in the Female Mammal, p. 532. Eds. G. E. Lamming and E. C. Amoroso. Butterworth, London,

Adams, C. E. (1970) Egg-uterus interrelationships. Adv. Biosci. 4, 149.

Arthur, A. T., Cowan, B. D. \& Daniel, J. G., JR (1972) Steroid binding to blastokinin. Fert. Steril. 23, 85.

BEIER, H. M. (1966) Das Proteinmilieu im Serum, Uterus und Blastocysten des Kaninchens vor der Nidation. In: Coll. Biochemie d. Morphogenese. Konstanz.

BEIER, H. M. (1967) Veränderungen am Proteinmuster des Uterus bei dessen Ernährungsfunktion für die Blastocyste des Kaninchens. Verh. dt. zool. Ges. 31, 139.

BEIER, H. M. (1968a) Biochemisch-entwicklungsphysiologische Untersuchungen am Proteinmileiu für die Blastocystenentwicklung des Kaninchens (Oryctolagus cuniculus). Zool. Fb. Anat. 85, 72.

Beier, H. M. (1968b) Uteroglobin: a hormone-sensitive endometrial protein involved in blastocyst development. Biochim. biophys. Acta, 160, 289.

BEIER, H. M. (1970a) Protein patterns of endometrial secretion in the rabbit. In: Ovo-Implantation Human, Gonadotrophins and Prolactin, p. 157. Eds. P. O. Hubinot, F. Leroy, G. Robyn and P. Leleux. Karger, Basel.

BEIER, H. M. (1970b) Hormonal stimulation of protease inhibitor activity in endometrial secretion during early pregnancy. Acta endocr., Copenh. 63, 141.

BeIER, H. M. (1971) Die Pseudogravidität des Kaninchens nach Stimulieurung mit Choriongonadotropin. Diss. med. Fak. Univ. Marburg, Marburg/Lahn.

BEIER, H. M. (1972) Biochemical approach to ovo-implantation. Workshop-Conference, I.C.E. Washington. Eds. R. O. Greep and K. Yoshinaga (in press).

BEIER, H. M. (1973) Die hormonelle Stewerung der Uterussekretion und frühen Embryonalentwicklung des Kaninchens. Habil.-Schrift, Univ. Kiel, Med. Fakultät, Kiel.

Beier, H. M. \& KühNel, W. (1973a) Pseudopregnancy in the rabbit after stimulation by human chorionic gonadotropin. Hormone Res. 4, 1.

BeIER, H. M. \& KüHNEL, W. (1973b) Die verzögerte Uterussekretion nach Oestrogeninjektionen beim graviden Kaninchen. Verh. anat. Ges. Köln 1972, Anat. Anz. Suppl (in press).

Beier, H. M., Kühnel, W. \& Petry, G. (1971) Uterine secretion proteins as extrinsic factors in preimplantation development. Adv. Biosci. 6, 165.

Beier, H. M., Kühnez, W. \& Petry, G. (1972) Morphologische und biochemische Befunde am pseudograviden Kaninchenendometrium nach gonadotroper Stimulierung. Verh. anat. Ges. Zagreb 1971, Anat. Anz. Suppl. 131, 445. 
Beier, H. M., Mootz, U. \& KüHNEL, W. (1972) Asynchrone Eitransplantationen während der verzögerten Uterussekretion beim Kaninchen. The 7th Int. Congr. Anim. Reprod. Artif. Insem., München, 3, 1891.

Beier, H. M., Petry, G. \& Kühnel, W. (1970) Endometrial secretion and early mammalian development. In: 21 st Coll. Ges. Biol. Chem. Mosbach 1970, p. 264. Eds. H. Gibian and E. J. Plotz. Springer, Berlin.

Blandau, R.J., Ed. (1971) The biology of the blastocyst. University of Chicago Press, Chicago and London.

Chang, M. C. (1950) Development and fate of transferred rabbit ova or blastocyst in relation to the ovulation time of recipients. 7. exp. Zool. 114, 197.

Daniel, J. C., JR (1971) Uterine proteins and embryonic development. Adv. Biosci. 6, 191.

DANiel, J. C., JR (1972) Local production of protein during implantation in the rabbit. 7 . Reprod. Fert. 31, 303.

Denker, H. W. (1971) Enzym-Topochemie von Frühentwicklung und Implantation des Kaninchens. III. Proteasen. Histochemie, 25, 344.

Denker, H. W. (1972) Blastocyst protease and implantation: effect of ovariectomy and progesterone substitution in the rabbit. Acta endocr., Copenh. 70, 591.

Dies, R. (1972) Hormonale Beeinflussung des Sekretproteinmusters und der Keimesentwickling im Genitaltrakt von Oryctolagus cuniculus. Naturwiss. Diss., Marburg.

Feigelson, M. \& Kay, E. (1972) Protein patterns of rabbit oviducal fluid. Biol. Reprod. 6, 244.

Hamner, C. E. (1971) Composition of oviductal and uterine fluids. Adv. Biosci. 6, 143.

Hamner, G. E. \& Fox, S. B. (1968) Effect of oestrogen and progesterone on physical properties of rabbit oviduct fluid. 7. Reprod. Fert. 16, 121.

Hamner, G. E. \& Fox, S. B. (1969) Biochemistry of oviductal secretions. In: The Mammalian Oviduct, p. 333. Eds. E. S. E. Hafez and R. J. Blandau. University of Chicago Press, Chicago and London.

Kirchner, C. (1969) Untersuchungen an uterusspezifischen Glycoproteinen während der frühen Gravidität des Kaninchens (Oryctolagus cuniculus). Wilhelm Roux Arch. EntwMech. Org. $164,97$.

KIRChNER, C. (1972) Immune histologic studies on the synthesis of a uterine-specific protein in the rabbit and its passage through the blastocyst coverings. Fert. Steril. 23, 131.

Kirchner, G., Hirschhäuser, C. \& Kionke, M. (1971) Protease activity in rabbit uterine secretion 24 hours before implantation. 7. Reprod. Fert. 27, 259.

Krishnan, R. S. \& Daniel, J. C., JR (1967) 'Blastokinin': inducer and regulator of blastocyst development in the rabbit uterus. Science, $\mathcal{N} . Y .158,490$.

Krishnan, R. S. \& Daniel, J. C., JR (1968) Composition of 'blastokinin' from rabbit uterus. Biochim. biophys. Acta, 168, 579.

Kühnel, W. \& Beier, H. M. (1973) Struktur und Sekretion des Tubenepithels nach Stimulierung des ovariellen Zyklus beim Kaninchen. Z. Zellforsch. mikrosk. Anat. (in press).

Kühnel, W., Beier, H. M. \& Petry, G. (1971) Untersuchungen zur hormonellen Regulation der Praeimplantationsphase der Gravidität. II. Histologische, topochemische und biochemische Analysen am hormonbehandelten, pseudograviden Kaninchenuterus. Cytobiologie, 4, 9.

Kulangara, A. C. (1972) Volume and protein concentration of rabbit uterine fluid. 7 . Reprod. Fert. 28, 419.

Kunitake, G. M., Nakamura, R. M., Wells, B. G. \& Moyer, D. L. (1965) Studies on uterine fluid. I. Disc electrophoretic and disc-gel Ouchterlony analysis of rat uterine fluid. Fert. Steril. 16, 120.

LUTWAK-MANN, C. (1955) Carbonic anhydrase in the female reproductive tract. Occurrence, distribution and hormonal dependence. 7. Endocr. 13, 26.

LutwaK-MANN, C. (1966) Some physiological and biochemical properties of the mammalian blastocyst. Bull. schweiz. Akad. med. Wiss. 22, 101.

LUTWAK-MANN, C. (1971) The rabbit blastocyst and its environment: physiological and biochemical aspects. In: Biology of the Blastocyst, pp. 243-260. Ed. R. J. Blandau. University of Chicago Press, Chicago and London.

Mastroinani, L., Urzua, M., Avalos, M. \& Stambaugh, R. (1969) Some observations on Fallopian tube fluid in the monkey. Am. 7. Obstet. Gynec. 103, 703.

Mastroianni, L., Urzua, M. \& Stambaugh, R. (1970) Protein patterns in monkey oviductal fluid before and after ovulation. Fert. Steril. 21, 817.

Mastroianni, L., Urzua, M. \& Stambaugh, R. (1972) The internal environmental fuids of the oviduct. In: Regulation of Mammalian Reproduction. NIH Conference. Eds. S. J. Segal, R. Crozier, P. A. Corfman and P. G. Condliffe. C. C. Thomas, Springfield, Illinois.

Moghissi, K. S. (1970) Human Fallopian tube fluid. I. Protein composition. Fert. Steril. 21, 821,

Mootz, U. (1971) Die Regulationsbefähigung der Keimscheibe von Oryctolagus cunicultus nach totaler Röntgenbestrahlung. Zool. 7b. Anat. 88, 587.

Murray, F. A., McGaughey, R. W. \& Yarus, M. J. (1972) Blastokinin: its size and shape, and an indication of the existence of sub-units. Fert. Steril. 23, 69.

Nachlas, M. M., Crawford, D. T. \& Seligman, A. M. (1957) The histochemical demonstration of leucine aminopeptidase. $\mathcal{7}$. Histochem. Cytochem. 5, 264. 
PETzoldr, U. (1971) Untersuchung über das anorganische Milieu in Uterus und Blastocyste des Kaninchens. Zool. Jb. Physiol. 75, 547.

Petzoldt, U., Dames, W., Gotrschewski, G. H. M. \& Neuhoff, V. (1972) Das Proteinmuster in frühen Entwicklungsstadien des Kaninchens. Cytobiologie, 5, 272.

Scrwick, H. G. (1965) Chemisch-entwicklungsphysiologische Beziehungen von Uterus zu Blastocyste des Kaninchens (Oryct. cuniculus). Wilhelm Roux Arch. EntwMech. Org. 156, 283.

Seamark, R. F. \& Lutwak-Mann, C. (1972) Progestins in rabbit blastocysts. F. Reprod. Fert. $29,147$.

Shapiro, S. S., Jentsch, J. P. \& YARd, A. S. (1971) Protein composition of rabbit oviducal fluid. $\mathcal{F}$. Reprod. Fert. 24, 403.

STEGNER, H.-E. (1969) Die funktionellen Wechselwirkungen zwischen Tube und befruchtetem Ei. Arch. Gynaek. 207, 136.

U'rzua, M. A., Stambaugh, R., Flickinger, G. \& Mastroianni, L. (1970) Uterine and oviduct fluid protein patterns in the rabbit before and after ovulation. Fert. Steril. 21, 860. 